\title{
Functional assessment of the pelvic floor muscles by electromyography: is there a normalization in data analysis? A systematic review
}

\author{
Avaliação funcional dos músculos do assoalho pélvico pela eletromiografia: existe a \\ normalização na análise de dados? Uma revisão sistemática \\ Evaluación funcional de los músculos del suelo pélvico por la electromiografía: ¿la \\ normalización existe en el análisis de datos? Una revisión sistemática

\begin{abstract}
Aline Moreira Ribeiro', Elaine Cristine Lemes Mateus-Vasconcelos ${ }^{2,3}$, Thaís Daniel da Silva ${ }^{4}$ Luiz Gustavo de Oliveira Brito ${ }^{5}$, Harley Francisco de Oliveira ${ }^{6}$
\end{abstract}

\begin{abstract}
This study aims to evaluate the method of analysis of electromyographic data considering the functional assessment of pelvic floor muscles (PFM). We have included in our search strategy the following databases: Medline, PubMed, Cochrane Central Register of Controlled Trials and Cochrane Database of Systematic Reviews, PEDro, and IBECS, considering articles published in the last ten years (2004-2014). The identified articles were independently examined by two evaluators, according to these inclusion criteria: (1) population: female adults; (2) PFM assessment by electromyography (EMG) with vaginal/ anal probe; and (3) description of how electromyographic data analysis is performed. The Newcastle-Ottawa Scale (NOS) was used to assess the risk of bias. We identified 508 articles, of which 23 were included in the review. The data showed differences between the collection protocols, and a significant number of studies did not normalize the electromyographic data. Physiotherapists are among the clinicians who most frequently use EMG to evaluate the function and dysfunction of the neuromuscular system. Although some previous studies have provided an overview to guide the evaluator in the assessment, few succeeding studies followed their recommendations.
\end{abstract}

Keywords | Pelvic Floor; Electromyography; Review.
RESUMO | Este estudo objetiva analisar o método de análise dos dados eletromiográficos na avaliação funcional dos músculos do assoalho pélvico (MAP). As bases de dados consultadas foram: Medline, PubMed, Cochrane Central Register of Controlled Trials e Cochrane Database of Systematic Reviews, PEDro e IBECS, considerando-se artigos publicados nos últimos dez anos (2004-2014). Os artigos identificados foram avaliados independentemente por dois avaliadores, de acordo com os critérios de inclusão: (1) população: mulheres adultas; (2) avaliação dos MAP utilizando a eletromiografia (EMG) com sonda vaginal ou anal; (3) descrição de como é feita a análise dos dados eletromiográficos. O instrumento Newcastle-Ottawa Scale (NOS) foi usado para avaliação da qualidade metodológica dos estudos. Foram identificados 508 artigos, dos quais 23 foram incluídos na revisão. Os dados mostraram diferenças entre os protocolos de coleta, e um número significativo de estudos não utilizaram a normalização na análise dos dados eletromiográficos. Os fisioterapeutas estão entre os profissionais que mais utilizam a EMG para avaliar a função e disfunção do sistema neuromuscular. Apesar de alguns estudos anteriores fornecerem uma visão geral para orientar o avaliador no uso deste instrumento, poucos estudos subsequentes seguiram suas recomendações.

Descritores | Diafragma da Pelve; Eletromiografia; Revisão.

'Physical therapist, professor of the course of Physical Therapy of the Instituto Federal de Educação, Ciência e Tecnologia do Rio de Janeiro Rio de Janeiro (RJ), Brazil.

${ }^{2}$ Physical therapist, professor of the course of Physiotherapy of the Centro Universitário Barão de Mauá - Ribeirão Preto (SP), Brazil. ${ }^{3}$ Centro de Reabilitação of the Clinical Hospital of the Faculdade de Medicina de Ribeirão Preto of the Universidade de São Paulo Ribeirão Preto (SP), Brazil.

${ }^{4}$ Physical therapist, resident physiotherapist of the Universidade Federal de São Paulo - São Paulo (SP), Brazil.

${ }^{5} \mathrm{PhD}$ of the Department of Gynecology and Obstetrics of the Faculdade de Medicina de Ribeirão Preto of the Universidade de São Paulo - Ribeirão Preto (SP), Brazil.

${ }^{6} \mathrm{PhD}$ of the Department of Internal Medicine of the Faculdade de Medicina de Ribeirão Preto of the Universidade de São Paulo Ribeirão Preto (SP), Brazil. 
RESUMEN ISe evaluó, en este estudio, el método de análisis de los datos electromiográficos en la evaluación funcional de los músculos del suelo pélvico. Las bases de datos consultadas fueron: Medline, PubMed, Cochrane Central Register of Controlled Trials, Cochrane Database of Systematic Reviews, PEDro y IBECS. La investigación fue refinada considerándose artículos publicados en los últimos diez años (2004 a 2014). Se evaluaron de forma independiente los artículos identificados por dos evaluadores, según los siguientes criterios de inclusión: (1) población: mujeres adultas; (2) evaluación de los músculos del suelo pélvico utilizándose la electromiografía (EMG) con sonda vaginal o anal; (3) descripción de cómo es el análisis de los datos electromiográficos. Se utilizó el instrumento Newcastle-Ottawa Scale (NOS) para evaluar la calidad metodológica de los estudios. Se identificaron 508 artículos y 23 de estos fueron incluidos en la revisión. Los datos mostraron diferencias entre los protocolos de recolección y un número significativo de estudios no utilizaron la normalización en el análisis de los datos electromiográficos. Los fisioterapeutas están entre los profesionales que más utilizan la EMG para evaluar la función y disfunción del sistema neuromuscular. Aunque algunos estudios anteriores proporcionen una visión general para orientar el evaluador en el uso de este instrumento, pocos estudios posteriores han seguido sus recomendaciones.

Palabras clave | Diafragma de la Pelvis; Electromiografía; Revisión.

\section{INTRODUCTION}

The correlation between pelvic floor muscles (PFM) strength and dysfunctions in this region is still an open field of research, with few published data. Several functional PFM assessment methods are used in clinical practice and research, such as digital palpation, perineometry, surface electromyography (sEMG), dynamometry, and imaging modalities, such as ultrasonography and magnetic resonance imaging ${ }^{1,2}$.

Among these assessment methods, electromyography (EMG) outstands as an alternative method to monitor muscle tone at rest, muscle strength, and muscular endurance, and to obtain data on the normal and abnormal physical functions of the PFM. EMG is indicated as a reliable and objective muscle evaluation method that causes no harm to patients ${ }^{3,4}$.

EMG monitors the electrical activity generated by the depolarization of muscle fibers, as a function of voltage effect over time. It is the algebraic sum of all the signals detected in a certain area and can be considered as an indirect measurement of muscle strength. The electrical activity can be collected either with surface or intramuscular electrodes ${ }^{1,5}$. Because PFMs lie deep to the skin surface and the superficial and deep layers of PFMs have distinct functions, to use surface electrodes adhered to the perineum is not ideal to study the deep layer of the PFMs, as unwanted activity (crosstalk) would inevitably be recorded from the superficial PFMs and potentially from other nearby muscles including the anal sphincter, the gluteus, and the obturator hip musculature. Considering that deep PFMs lie adjacent to the vaginal walls, electrodes positioned against the lateral vaginal walls are a convenient mean to record their EMG activity ${ }^{6}$.

Thus, in clinical practice, surface electrodes (vaginal and anal probes) are more widely used due to the high sensitivity of the perineal region and the skills required in using the needle or fine-wire electrodes ${ }^{2,7}$.

The characteristics of the amplitude and frequency of EMG signal are sensible to intrinsic (type of muscle fiber, depth, diameter and amount of tissue between the muscle and electrode) and extrinsic factors (location, orientation and shape of the area of the electrodes). Therefore, the signal amplitude cannot be analyzed directly ${ }^{3,5,8}$.

The "normalization" is required to analyze and compare EMG signals from different individuals, muscles and acquisition. It is a form of transforming the absolute amplitude values into relative values relating to an amplitude value characterized as $100 \%{ }^{8}$. There are several forms of normalization of EMG signal. Among them, the most used is the normalization by maximum voluntary contraction (MVC), in which the reference to the standards is the highest value found among certain muscle contractions in question ${ }^{9}$.

Normalization prevents interference on the intensity of contraction, since they remove the effect of other factors that influence the signal capture. Thus, we can compare different muscles and individuals to the amount of energy produced during a certain contraction only after the process of normalization ${ }^{5}$.

However, no normal standards or references have been established for EMG or differences in the methodology, types of probe and collection protocols used. The way these data are analyzed can make the comparison of studies and systematic assessments of results found difficult. 
Thus, the aim of this study was to evaluate the methods of analysis of EMG data in studies that encompass the PFM functional evaluation.

\section{METHODOLOGY}

\section{Eligibility criteria}

Inclusion and exclusion criteria are:

- Inclusion criteria:

- Scientific articles published in the last ten years (2004-2014), which aimed to perform pelvic floor muscles (PFM) functional assessment using EMG;

- Articles published in English and in full.

Design

- Full-text articles of cross-sectional studies.

Participants

- Female adult participants.

PFM functional assessment

- Performed using sEMG with a vaginal/anal probe;

- With a description of how the analysis of EMG data is performed.

- Exclusion criteria:

- Studies including children and adolescents;

- Studies including men;

- Animal experiments;

- Treatment with EMG biofeedback, without EMG rating;

- Other exams that included EMG (urodynamic, for example);

- Modified custom probes;

- Review articles, guidelines and other studies with different design.

\section{Information sources and search}

To select studies related to the topic investigated, we have performed a computer-aided and manual search between September 2013 and February 2014. The consulted databases included: Medline PubMed, Cochrane Central Register of Controlled Trials (CENTRAL), Cochrane Database of Systematic Reviews, PEDro, and IBECS. We have limited the search to English-language manuscripts published between 2004 and 2014. Articles published in full and available in the databases were included in this study. Our search strategy was broad, aiming to have as many manuscripts as possible to make a good triage. The following keyword was used: "pelvic floor electromyography". Articles identified in the initial search strategy were selected according to the inclusion criteria.

This review followed the methodological quality parameters of systematic reviews and the Preferred Reporting Items for Systematic Reviews and MetaAnalyses (PRISMA) criteria were observed.

\section{Data collection process}

A standardized data extraction form was used to collect the following data: authors, year, publication, country of origin, study design, sample, age (years), probe used, data collection protocol and whether the normalization of electromyographic data was performed. This process was performed using two independent raters (AMR and ECLMV).

\section{Risk of bias assessment}

The risk of bias was assessed using the NewcastleOttawa Scale (NOS). The original NOS was developed to assess the quality of the observational studies; it contains eight items that analyze three dimensions: selection, comparability and outcome (in cohort studies) or exposure (case-control studies). There is a series of options for each item, which reflects the quality of the studies and is scored by a star: the higher the number of the star, the higher is the study quality ${ }^{10}$.

A study may receive a maximum of one star for each numbered item within the "selection" and "outcome" categories. A maximum of two stars may be given for "comparability". The total score is nine: four stars in "selection", two stars in "comparability" and three stars in "outcome"10.

\section{Summary measures}

The variables analyzed were: type of probe used in the collection of EMG data; collection protocol; and normalized EMG data. Data was summarized in tables. A qualitative analysis was undertaken due to trial heterogeneity and lack of standardized outcome measures. Therewith, a meta-analysis was not performed. 


\section{RESULTS}

\section{Study selection}

A total of 213 publications were identified from MEDLINE, 221 from PubMed, 51 from CENTRAL and the Cochrane Database of Systematic Reviews, 18 from PEDro, and five from IBECS, resulting in 508 related publications. Of the articles identified, 107 were selected after applying the established inclusion and exclusion criteria. Only 23 articles were included for this review (Figure 1).

\section{Assessment of quality of manuscripts}

Table 1 summarizes the results of the methodological quality assessment.

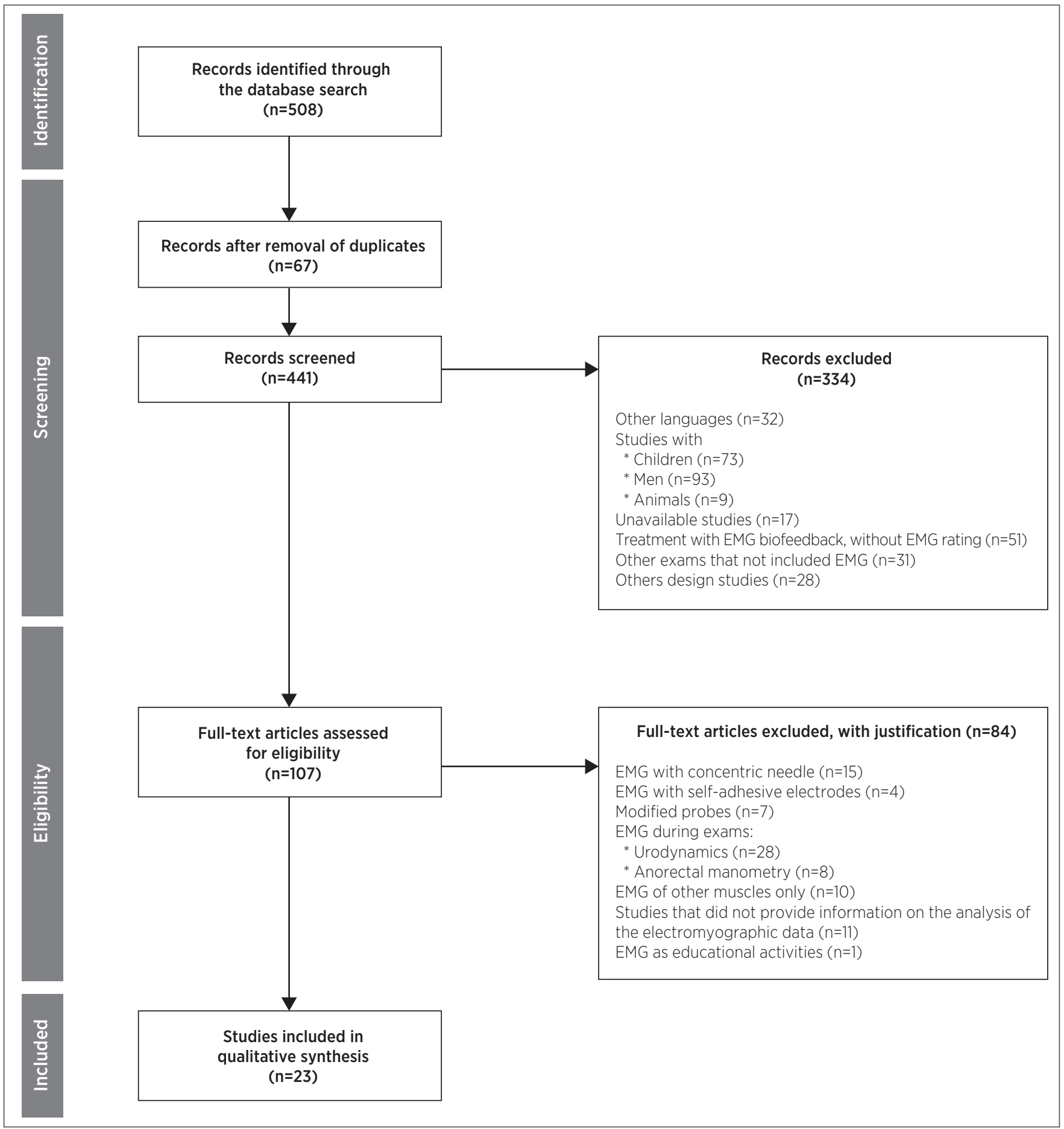

Figure 1. Flowchart with the numbers of articles identified, excluded, and included in the systematic review 
Table 1. Evaluation of the methodological quality of selected studies.

\begin{tabular}{|c|c|c|c|c|}
\hline References & Selecti & tion & Comparability & Outcome \\
\hline Auchincloss and McLean" & * * & * & - & * \\
\hline Botelho et al. ${ }^{3}$ & ** & * & - & * \\
\hline Chen et al. ${ }^{2}$ & ** & * & - & * \\
\hline Devreese et al.13 & ** & * & * & * \\
\hline Frederice, Amaral and Ferreira ${ }^{14}$ & * * & * & - & * \\
\hline Grape, Dedering and Jonasson ${ }^{15}$ & ** & * & - & * \\
\hline Halski et al. ${ }^{16}$ & * * & * & - & * \\
\hline Halski, Ptaszkowski, Słupska and Dymarek ${ }^{17}$ & ** & * & - & * \\
\hline Junginger, Baessler, Sapsford and Hodges ${ }^{18}$ & * * & * & - & * \\
\hline Lauper, Kuhn, Gerber, Luginbühl and Radlinger ${ }^{19}$ & * * & * & * & * \\
\hline Luginbuehl et al. ${ }^{20}$ & * * & * & * & * \\
\hline Pereira et al. ${ }^{21}$ & * * & * & * & * \\
\hline Petricelli et al. ${ }^{22}$ & $* *$ & * & - & * \\
\hline Resende et al. ${ }^{23}$ & * * & * & * & * \\
\hline Resende et al. ${ }^{24}$ & ** & * & - & * \\
\hline Sapsford, Richardson, Maher and Hodges ${ }^{25}$ & * * & * & * & * \\
\hline Smith, Coppieters and Hodges ${ }^{26}$ & ** & * & * & * \\
\hline Smith, Coppieters and Hodges ${ }^{27}$ & * * & * & * & * \\
\hline Soljanik et al. ${ }^{28}$ & ** & * & - & * \\
\hline Stüpp et al. ${ }^{29}$ & * * & * & - & * \\
\hline Thompson, O'Sullivan, Briffa and Neumann ${ }^{30}$ & * * & * & - & * \\
\hline Thompson. O'Sullivan, Briffa and Neumann ${ }^{31}$ & * * & * & - & * \\
\hline Zhang, Wang and Zheng ${ }^{32}$ & * * & * & * & * \\
\hline
\end{tabular}

\section{General characteristics of the studies}

The characteristics of the articles included in this study are listed in Table 2. The sample sizes ranged from nine to 307 women (mean 50.0; median 30.0). The mean age of the participants was 35.2 years (median 30.4; range 22-63). Seven studies were performed in Brazil and six in Australia.

Table 2. General characteristics of the 23 selected studies.

\begin{tabular}{|c|c|c|c|c|c|}
\hline Authors, year & Publication & Country & Study design & Subjects (age in years) & Objectives \\
\hline $\begin{array}{l}\text { Auchincloss and } \\
\text { McLean, 2009"11 }\end{array}$ & $\begin{array}{l}\text { Journal of } \\
\text { Neuroscience } \\
\text { Methods }\end{array}$ & Canada & Cross-sectional & $\begin{array}{l}10 \text { women } \\
(30.0 \pm 3.9)\end{array}$ & $\begin{array}{l}\text { To determine whether PFM activation } \\
\text { amplitude changes when different } \\
\text { vaginal probes are inserted into } \\
\text { the vagina. }\end{array}$ \\
\hline $\begin{array}{l}\text { Botelho et al., } \\
2013^{3}\end{array}$ & $\begin{array}{l}\text { Neurourology and } \\
\text { Urodynamics }\end{array}$ & Brazil & Cross-sectional & $\begin{array}{l}307 \text { women } \\
(23.93 \pm 5.78)\end{array}$ & $\begin{array}{l}\text { To investigate if digital palpation of PFMs } \\
\text { is correlated with its electromyographic } \\
\text { activity. }\end{array}$ \\
\hline Chen et al., 200912 & $\begin{array}{l}\text { The Journal of } \\
\text { Urology }\end{array}$ & Taiwan & Cross-sectional & $\begin{array}{c}31 \text { women } \\
(46.48 \pm 7.24)\end{array}$ & $\begin{array}{l}\text { To examine the effects of passive and } \\
\text { active ankle flexion on PFM activity } \\
\text { during exercises. }\end{array}$ \\
\hline $\begin{array}{l}\text { Devreese et al., } \\
2007^{13}\end{array}$ & $\begin{array}{l}\text { The Journal of } \\
\text { Urology }\end{array}$ & Belgium & Cross-sectional & $\begin{array}{c}82 \text { women } \\
\text { (32 continent, } 52.38 \pm 9.68 ; \\
50 \text { incontinent, } \\
52.78 \pm 7.99)\end{array}$ & $\begin{array}{l}\text { To contribute to the understanding of } \\
\text { the mechanisms we investigated, the } \\
\text { contraction sequence of superficial } \\
\text { versus deep PFM in six positions of } \\
\text { continent and incontinent women. }\end{array}$ \\
\hline $\begin{array}{l}\text { Frederice et al., } \\
2013^{14}\end{array}$ & $\begin{array}{l}\text { Journal of } \\
\text { Obstetrics and } \\
\text { Gynaecology } \\
\text { Research }\end{array}$ & Brazil & Cross-sectional & $\begin{array}{l}91 \text { women } \\
(24.3 \pm 4.9)\end{array}$ & $\begin{array}{l}\text { To evaluate PFM function and its } \\
\text { association with urinary symptoms in the } \\
\text { third trimester of pregnancy. }\end{array}$ \\
\hline Grape et al., $2009^{15}$ & $\begin{array}{l}\text { Neurourology and } \\
\text { Urodynamics }\end{array}$ & Sweden & Cross-sectional & $\begin{array}{c}17 \text { women } \\
(26 \text {, range } 22-34)\end{array}$ & $\begin{array}{l}\text { To evaluate the retest reliability of } \\
\text { repeated intravaginal EMG of the PFM } \\
\text { in healthy women, who were able to } \\
\text { correctly perform PFM contractions. }\end{array}$ \\
\hline
\end{tabular}


Table 2. Continuation

\begin{tabular}{|c|c|c|c|c|c|}
\hline Authors, year & Publication & Country & Study design & Subjects (age in years) & Objectives \\
\hline Halski et al., $2013^{16}$ & $\begin{array}{l}\text { BioMed Research } \\
\text { International }\end{array}$ & Poland & Cross-sectional & $\begin{array}{l}20 \text { women } \\
(22.3 \pm 1.28)\end{array}$ & $\begin{array}{l}\text { To determine how the depth of probe } \\
\text { placement affects functional and resting } \\
\text { bioelectrical activity of the PFM and } \\
\text { whether the recorded signal might be } \\
\text { dependent on the direction in which the } \\
\text { probe is rotated. }\end{array}$ \\
\hline Halski et al., $2014^{17}$ & $\begin{array}{l}\text { BioMed Research } \\
\text { International }\end{array}$ & Poland & Cross-sectional & $\begin{array}{c}16 \text { women } \\
(63.1 \pm 4,1 \text {, range } 55-70)\end{array}$ & $\begin{array}{l}\text { To evaluate resting and functional } \\
\text { bioelectrical activity of the PFM and } \\
\text { synergistic muscles, depending on the } \\
\text { orientation of the pelvis, in anterior (P1) } \\
\text { and posterior (P2) pelvic tilt. }\end{array}$ \\
\hline $\begin{array}{l}\text { Junginger et al., } \\
2010^{18}\end{array}$ & $\begin{array}{l}\text { International } \\
\text { Urogynecology } \\
\text { Journal }\end{array}$ & Australia & Cross-sectional & $\begin{array}{c}9 \text { women } \\
\text { (42, range 32-59) }\end{array}$ & $\begin{array}{l}\text { To investigate the relationship between } \\
\text { bladder neck displacement, EMG activity } \\
\text { of the PFM and abdominal muscles } \\
\text { and intra-abdominal pressure during } \\
\text { different pelvic floor and abdominal } \\
\text { contractions. }\end{array}$ \\
\hline $\begin{array}{l}\text { Lauper et al. } \\
2009^{19}\end{array}$ & $\begin{array}{l}\text { Neurourology and } \\
\text { Urodynamics }\end{array}$ & Switzerland & Cross-sectional & $\begin{array}{c}38 \text { women } \\
\text { (21 control, 30.0 } \pm 4.7 \\
17 \text { post-partum, } 31.7 \pm 3.4)\end{array}$ & $\begin{array}{l}\text { To determine if two different } \\
\text { whole-body vibrations, sinusoidal } \\
\text { vibration and SR-WBV, lead to a } \\
\text { reactive activation of PFM when using } \\
\text { various intensities. }\end{array}$ \\
\hline $\begin{array}{l}\text { Luginbuehl et al., } \\
2012^{20}\end{array}$ & $\begin{array}{l}\text { Neurourology and } \\
\text { Urodynamics }\end{array}$ & Switzerland & Cross-sectional & $\begin{array}{c}50 \text { women } \\
(28 \mathrm{np} / \mathrm{pp} \text { group, } \\
47.0 \pm 9.6 ; 22 \mathrm{pp} \text { group } \\
33.1 \pm 4.8)\end{array}$ & $\begin{array}{l}\text { To determine the SR-WBV load modality } \\
\text { regarding PFM activity to complete the } \\
\text { SR-WBV training methodology for future } \\
\text { PFM training with SR-WBV. }\end{array}$ \\
\hline Pereira et al., $2013^{21}$ & $\begin{array}{l}\text { Neurourology and } \\
\text { Urodynamics }\end{array}$ & Brazil & Cross-sectional & $\begin{array}{l}81 \text { women } \\
\text { (20 nulliparous, } 24.4 \pm 3.6 \\
25 \text { pregnant, } 24.6 \pm 5.6 \\
19 \text { vaginal delivery, } \\
21.8 \pm 3.1 ; 17 \text { cesarean } \\
\text { section, } 23.1 \pm 5.9 \text { ) }\end{array}$ & $\begin{array}{l}\text { To simultaneously evaluate both } \\
\text { transversus abdominis/internal oblique } \\
\text { muscles and PFM during isometric } \\
\text { exercises in nulliparous, pregnant, and } \\
\text { postpartum women. }\end{array}$ \\
\hline $\begin{array}{l}\text { Petricelli et al., } \\
2014^{22}\end{array}$ & $\begin{array}{l}\text { BioMed Research } \\
\text { International }\end{array}$ & Brazil & Cross-sectional & $\begin{array}{c}60 \text { women } \\
(26.06 \pm 5.58)\end{array}$ & $\begin{array}{l}\text { To compare the role of the PFM between } \\
\text { nulliparous and multiparous women } \\
\text { in the third trimester of pregnancy, } \\
\text { analyzing the relationship between EMG, } \\
\text { vaginal palpation (modified Oxford } \\
\text { Grading Scale), and perineal distensibility } \\
\text { (EPI-NO). }\end{array}$ \\
\hline $\begin{array}{l}\text { Resende et al., } \\
2012^{23}\end{array}$ & $\begin{array}{l}\text { International } \\
\text { Urogynecology } \\
\text { Journal }\end{array}$ & Brazil & Cross-sectional & $\begin{array}{l}30 \text { women } \\
\text { (Group 1, 28.2 } \pm 6.5 \\
\text { Group 2, 26.4 }\end{array}$ & $\begin{array}{l}\text { To compare the MVC and strength of } \\
\text { PFM of pregnant and non-pregnant } \\
\text { women using SEMG. }\end{array}$ \\
\hline $\begin{array}{l}\text { Resende et al., } \\
2011^{24}\end{array}$ & $\begin{array}{l}\text { International } \\
\text { Urogynecology } \\
\text { Journal }\end{array}$ & Brazil & Cross-sectional & $\begin{array}{l}34 \text { women } \\
(28 \pm 5.9)\end{array}$ & $\begin{array}{l}\text { To determine whether Paula method } \\
\text { of circular muscles contraction (those } \\
\text { surrounding the eyes, mouth and } \\
\text { fingers) can increase PFM activity. }\end{array}$ \\
\hline $\begin{array}{l}\text { Sapsford et al., } \\
2008^{25}\end{array}$ & $\begin{array}{l}\text { Archives of } \\
\text { Physical Medicine } \\
\text { and Rehabilitation }\end{array}$ & Australia & Cross-sectional & $\begin{array}{c}17 \text { women } \\
\text { (9 asymptomatic, } \\
45, \text { range } 32-66 ; 8 \\
\text { symptomatic, } 41.8 \text {, range } \\
\text { 33-55) }\end{array}$ & $\begin{array}{l}\text { To determine whether resting activity of } \\
\text { the PFM and abdominal muscles varied } \\
\text { in different sitting postures in parous } \\
\text { women with and without SUI. }\end{array}$ \\
\hline Smith et al., $2007^{26}$ & $\begin{array}{l}\text { Neurourology and } \\
\text { Urodynamics }\end{array}$ & Australia & Cross-sectional & $\begin{array}{l}30 \text { women } \\
\text { (14 continent, } 52.5 \pm 12.5 \\
16 \text { incontinent, } 49.8 \pm 12.0 \\
7 \text { mild-incontinence, } \\
48.1 \pm 12.2 ; 9 \text { more severe } \\
\text { incontinence, } 51.0 \pm 12.4)\end{array}$ & $\begin{array}{l}\text { To determine whether activity of the } \\
\text { PFM and abdominal muscles differs } \\
\text { between continent and incontinent } \\
\text { women in response to a postural } \\
\text { perturbation with a moderately full or } \\
\text { empty bladder. }\end{array}$ \\
\hline Smith et al., $2008^{27}$ & $\begin{array}{l}\text { Neurourology and } \\
\text { Urodynamics }\end{array}$ & Australia & Cross-sectional & $\begin{array}{l}29 \text { women } \\
\text { (16 with SUI, 49.8 } \pm 12.0 \\
13 \text { controls, } 53.1 \pm 12.7 \text { ) }\end{array}$ & $\begin{array}{l}\text { To investigate whether there are } \\
\text { differences in center of pressure } \\
\text { displacement, trunk motion, and trunk } \\
\text { muscle activity in women with and } \\
\text { without SUI during static balance } \\
\text { tasks when the bladder is empty and } \\
\text { moderately full. }\end{array}$ \\
\hline
\end{tabular}


Table 2. Continuation

\begin{tabular}{|c|c|c|c|c|c|}
\hline Authors, year & Publication & Country & Study design & Subjects (age in years) & Objectives \\
\hline $\begin{array}{l}\text { Soljanik et al., } \\
2012^{28}\end{array}$ & $\begin{array}{l}\text { Archives of } \\
\text { Gynecology and } \\
\text { Obstetrics }\end{array}$ & Germany & Cross-sectional & $\begin{array}{l}23 \text { women } \\
(22 \pm 3.7)\end{array}$ & $\begin{array}{l}\text { To evaluate the role of the ischioanal } \\
\text { fossa in functional relations between the } \\
\text { levator ani and gluteus maximus muscles } \\
\text { in healthy female volunteers. }\end{array}$ \\
\hline Stüpp et al., $2011^{29}$ & $\begin{array}{l}\text { International } \\
\text { Urogynecology } \\
\text { Journal }\end{array}$ & Brazil & Cross-sectional & $\begin{array}{l}34 \text { women } \\
(28.1 \pm 6.0)\end{array}$ & $\begin{array}{l}\text { To investigate PFM and transversus } \\
\text { abdominis activation during the } \\
\text { abdominal hypopressive technique } \\
\text { through sEMG. }\end{array}$ \\
\hline $\begin{array}{l}\text { Thompson et al., } \\
2006^{30}\end{array}$ & $\begin{array}{l}\text { Neurourology and } \\
\text { Urodynamics }\end{array}$ & Australia & Cross-sectional & $\begin{array}{c}13 \text { women } \\
(38 \pm 7)\end{array}$ & $\begin{array}{l}\text { To investigate the muscle activation } \\
\text { patterns of the abdominopelvic region } \\
\text { used by incontinent women during } \\
\text { a PFM contraction and a Valsalva } \\
\text { maneuver compared to healthy and } \\
\text { asymptomatic subjects. }\end{array}$ \\
\hline $\begin{array}{l}\text { Thompson et al., } \\
2006 b^{31}\end{array}$ & $\begin{array}{l}\text { Neurourology and } \\
\text { Urodynamics }\end{array}$ & Australia & Cross-sectional & $\begin{array}{l}13 \text { women } \\
(37 \pm 9)\end{array}$ & $\begin{array}{l}\text { To investigate the different muscle } \\
\text { activation patterns around the } \\
\text { abdominopelvic cavity in continent } \\
\text { women and their effect on pressure } \\
\text { generation during a correct PFM } \\
\text { contraction and a Valsalva maneuver. }\end{array}$ \\
\hline $\begin{array}{l}\text { Zhang et al., } \\
2006^{32}\end{array}$ & $\begin{array}{l}\text { International } \\
\text { Journal of } \\
\text { Gynecology and } \\
\text { Obstetrics }\end{array}$ & China & Cross-sectional & $\begin{array}{c}114 \text { women } \\
\text { (57 with SUI, 41.3 } \pm 10.2 \text {; } \\
57 \text { controls, } 38.8 \pm 11 \text { ) }\end{array}$ & $\begin{array}{l}\text { To obtain perineal electrophysiological } \\
\text { data and assess the clinical usefulness of } \\
\text { measuring the sEMG activity of the PFM } \\
\text { in predicting and diagnosing SUI. }\end{array}$ \\
\hline
\end{tabular}

EMG: electromyography; MVC: maximal voluntary contraction; PFM: pelvic floor muscles; SR-WBV: stochastic resonance whole-body vibration; SUI: stress urinary incontinence; np: nulliparous; pp: primiparous

\section{Characteristics of data collection and analysis of surface electromyography}

The type of vaginal probe used varied between the studies. The most commonly used were FemiScan $(n=4)$ and Periform $(n=9)$. One study did not mention the type of vaginal probe used. The EMG data collection protocols also varied. Only one study examined the evaluation of the two separate types of muscle fibers (types I and II). Six studies evaluated the PFM in other positions besides the supine position; and three, during effort (cough) or Valsalva maneuver. Only four studies reported a normalization of the sEMG data for analysis.

Table 3. Characteristics of the probe used, collection protocol and other data on EMG

\begin{tabular}{|c|c|c|c|c|}
\hline Authors, year & Probe used & Data collection protocol & Frequencies and approaches to filter the signal & Normalization? \\
\hline $\begin{array}{l}\text { Auchincloss } \\
\text { and McLean, } \\
2009^{11}\end{array}$ & $\begin{array}{l}\text { Vaginal: } \\
\text { Periform and } \\
\text { FemiScan }\end{array}$ & One MVC and maximal effort cough. & $\begin{array}{l}\text { The signals were preamplified using a Delsys } \mathrm{S}^{\mathrm{TM}} \mathrm{DE}-2.1 \\
\text { Sensor for active electrode amplifiers }(200 \times) \text { before final } \\
\text { amplification using Delsys }{ }^{\mathrm{TM}} \mathrm{AMT}-8 \text { amplifiers [common } \\
\text { mode rejection ratio }(\mathrm{CMRR})=90 \mathrm{~dB} \text { at } 60 \mathrm{~Hz} \text {, bandwidth of } \\
20-450 \mathrm{~Hz} \text {, input impedance }>10^{15} \Omega \text { ] to produce an overall } \\
\text { gain of } 1000 \text {. }\end{array}$ & No \\
\hline $\begin{array}{l}\text { Botelho et al., } \\
2013^{3}\end{array}$ & $\begin{array}{l}\text { Vaginal: } \\
\text { PhysioMed } \\
\text { Services }\end{array}$ & Three 5-s MVCs with 10-s rest. & $\begin{array}{l}\text { Band-pass filter with cutoff frequencies at } 20-500 \mathrm{~Hz} \text {, an } \\
\text { amplifier gain of 1,000 times and a CMRR }>120 \mathrm{~dB} \text {. A } 12 \text {-bit } \\
\text { A/D signal converter plate was used, to convert analog } \\
\text { signals into digital ones with a } 2.0 \mathrm{kHz} \text { anti-aliasing filter } \\
\text { sampling frequency, with an input range of } 5 \mathrm{mN} \text {. }\end{array}$ & No \\
\hline $\begin{array}{l}\text { Chen et al., } \\
2009^{12}\end{array}$ & $\begin{array}{l}\text { Vaginal: } \\
\text { FemiScan }\end{array}$ & $\begin{array}{l}\text { One contraction standing and one } \\
\text { contraction in eight different positions } \\
\text { of the ankle joint. }\end{array}$ & No description. & No \\
\hline $\begin{array}{l}\text { Devreese et al., } \\
2007^{13}\end{array}$ & $\begin{array}{l}\text { Vaginal: } \\
\text { No } \\
\text { description }\end{array}$ & $\begin{array}{l}\text { Supine + knees flexed, supine + knees } \\
\text { straight, sit leaning forward, sit upright, } \\
\text { stand leaning forward and stand } \\
\text { upright: } 2 \text {-min rest preceded by a MVC } \\
\text { for } 6 \text { s. The onset of increased activity } \\
\text { was defined as any muscle activity } \\
\text { with a minimum amplitude of a sliding } \\
\text { window of } 25 \text { ms exceeding resting } \\
\text { EMG by } 2 \text { SD. }\end{array}$ & $\begin{array}{l}\text { Band-pass filter of } 10 \text { to } 500 \mathrm{~Hz} \text {. Data were sampled by a } \\
12 \text { - bit analog-to-digital converter at a rate of } 1,000 \text { samples } \\
\text { per second, stored on a computer, full-wave rectified and } \\
\text { low-pass filtered at } 50 \mathrm{~Hz} \text { to smooth the data. }\end{array}$ & No \\
\hline
\end{tabular}


Table 3. Continuation

\begin{tabular}{|c|c|c|c|c|}
\hline Authors, year & Probe used & Data collection protocol & Frequencies and approaches to filter the signal & Normalization? \\
\hline $\begin{array}{l}\text { Frederice et al., } \\
2013^{14}\end{array}$ & $\begin{array}{l}\text { Vaginal: } \\
\text { Miotec }\end{array}$ & $\begin{array}{l}\text { Basal tone at rest, one contraction } \\
\text { with } 1 \text {-min rest, } \mathrm{MVC} \text { (highest } \\
\text { of } 3 \text { contractions), and one } 10-\mathrm{s} \\
\text { contraction. }\end{array}$ & No description. & No \\
\hline $\begin{array}{l}\text { Grape et al., } \\
2009^{15}\end{array}$ & $\begin{array}{l}\text { Vaginal: } \\
\text { FemiScan }\end{array}$ & $\begin{array}{l}\text { Three series of contractions with } 10 \text {-s } \\
\text { sustenance and } 10 \text {-s rest. }\end{array}$ & $\begin{array}{l}\text { A band-pass filter of } 8 \text { to } 500 \mathrm{~Hz} \text { ( } 3 \mathrm{~dB} \text { points) and a low- } \\
\text { pass filter of } 500 \mathrm{~Hz} \text { was used. The signal was sampled at } \\
10 \mathrm{~Hz} \text { after full-wave rectification. }\end{array}$ & No \\
\hline $\begin{array}{l}\text { Halski et al., } \\
2013^{16}\end{array}$ & $\begin{array}{l}\text { Vaginal: } \\
\text { Periprobe } \\
\text { Optima } 3\end{array}$ & $\begin{array}{l}\text { Standing position: five contractions } \\
\text { with } 5 \text {-s rest between each } \\
\text { contraction (resting activity). }\end{array}$ & $\begin{array}{l}\text { This device is characterized by a continuous amplitude } \\
\text { of } 0.2-2000 \mu \mathrm{VRMS} \text { in the frequency band of } 2-100 \mathrm{~Hz} \\
\text { and pulse-width modulation from } 50-450 \mu \mathrm{S} \text { for signals } \\
\text { recorded generated by muscles. Device sensitivity is } \\
\text { established at a level of } 0.1 \mu \mathrm{V} \text { ( } 4 \% \text { accuracy; readings } \\
\pm 0.3 \mathrm{mV} \text { at } 200 \mathrm{~Hz} \text { ), with selectable band-pass filter } \\
(3 \mathrm{~dB} \text { bandwidth) and } 50 \mathrm{~Hz} \text { notch filter ( } 33 \mathrm{~dB} ; 0.1 \% \\
\text { accuracy). }\end{array}$ & No \\
\hline $\begin{array}{l}\text { Halski et al., } \\
2014^{17}\end{array}$ & $\begin{array}{l}\text { Vaginal: } \\
\text { Lifecare } \\
\text { PR-02 } \\
\text { Vaginal Probe }\end{array}$ & $\begin{array}{l}\text { EMG activity was recorded with } \\
\text { the pelvis rotated forward (P1) and } \\
\text { backward (P2) around the transverse } \\
\text { axis. In } \mathrm{P} 1 \text { and } \mathrm{P} 2 \text {, the participants } \\
\text { made five } 5 \text {-s MVCs (functional } \\
\text { SEMG activity) with a } 5 \text {-s rest } \\
\text { (resting sEMG activity). They took } 60 \\
\text { s of rest between trials. }\end{array}$ & $\begin{array}{l}\text { Analog output gain: } 1000 \text { standard }(5000 \text { selected } \\
\text { units); minimum CMRR: } 100 \mathrm{~dB} \text { at } 50-60 \mathrm{~Hz} \text {; input } \\
\text { impedance }>100 \mathrm{M} \Omega \text { on sEMG channels (isolated to }>3000 \\
\text { V; sEMG amplifier performance: } 1 \mu \mathrm{V} \text { sensitivity and <1 } \\
\mu V R M S \text { baseline noise; data acquisition: } 8 \text { channels of } 12- \\
\text { bit resolution, and USB update to PC every millisecond; } \\
\text { cutoff of high-pass filter: } 10 \mathrm{~Hz} \text { first-order filter on sEMG } \\
\text { channels; selectable low-pass cutoff of } 500 \text { or } 1000 \mathrm{~Hz} \\
\text { on sEMG channels. }\end{array}$ & No \\
\hline $\begin{array}{l}\text { Junginger et } \\
\text { al., } 2010^{18}\end{array}$ & $\begin{array}{l}\text { Vaginal: } \\
\text { Periform }\end{array}$ & One 5-s MVC with 30- to 120 -s rest. & $\begin{array}{l}\text { EMG data were amplified } 2,000 \text { times, bandpass-filtered } \\
\text { between } 10 \mathrm{~Hz} \text { to } 1 \mathrm{kHz} \text { and sampled at } 2 \mathrm{kHz} \text {. }\end{array}$ & Yes \\
\hline $\begin{array}{l}\text { Lauper et al., } \\
2009^{19}\end{array}$ & $\begin{array}{l}\text { Vaginal: } \\
\text { Periform }\end{array}$ & PFM activity at rest and in 5-s MVC. & $\begin{array}{l}\text { The EMG was sampled at a rate of } 1 \mathrm{kHz} \text {, the cutoff } \\
\text { frequency of the low-pass filter (Butterworth, } 24 \mathrm{~dB} / \\
\text { Oct.) was set at } 500 \mathrm{~Hz} \text {. Expecting vibration artifacts } \\
\text { in the EMG, no high-pass filter was applied to detect } \\
\text { the fundamental frequency of vibration as well as the } \\
\text { harmonic content in the EMG signal. }\end{array}$ & Yes \\
\hline $\begin{array}{l}\text { Luginbuehl et } \\
\text { al., } 2012^{20}\end{array}$ & $\begin{array}{l}\text { Vaginal: } \\
\text { Periform }\end{array}$ & $\begin{array}{l}\text { Orthostatism: PFM activity at rest } \\
\text { and two 5-s MVCs with } 60 \text {-s rest. }\end{array}$ & $\begin{array}{l}\text { The EMG signal was transmitted to a measurement } \\
\text { amplifier (UMVE, uk-labs). The cutoff frequency of the } \\
\text { low-pass filter was set at } 500 \mathrm{~Hz} \text { to avoid aliasing in } \\
\text { accordance with the Nyquist-Shannon sampling theorem. }\end{array}$ & Yes \\
\hline $\begin{array}{l}\text { Pereira et al., } \\
2013^{21}\end{array}$ & $\begin{array}{l}\text { Vaginal: } \\
\text { PHYSIOMED } \\
\text { Services }\end{array}$ & Three 5-s MVCs with 10-s rest & $\begin{array}{l}\text { Band-pass filter with cutoff frequencies at } 20-500 \mathrm{~Hz} \text {, } \\
\text { an amplifier gain of } 1,000 \text { and a CMRR }>120 \mathrm{~dB} \text {. A } 12 \text {-bit } \\
\text { A/D signal converting plate was used to convert analog } \\
\text { signals to digital ones with a } 2.0 \mathrm{kHz} \text { anti-aliasing filter } \\
\text { sampling frequency, with an input range of } 5 \mathrm{mn} \text {. }\end{array}$ & No \\
\hline $\begin{array}{l}\text { Petricelli et al., } \\
2014^{22}\end{array}$ & $\begin{array}{l}\text { Vaginal: } \\
\text { Cone-shaped } \\
\text { intravaginal } \\
\text { sensor } \\
\text { (Chattanooga } \\
\text { Group) }\end{array}$ & $\begin{array}{l}\text { Three MVCs followed by relaxation } \\
(10 \text { s). The best of the three } \\
\text { contractions was selected for } \\
\text { the study. }\end{array}$ & $\begin{array}{l}\text { This is a signal processer with band-pass filters, cutoff } \\
\text { frequencies of } 20-500 \mathrm{~Hz} \text {, instrumentation preamplifier } \\
\text { ( } 20 \text {-fold gain), differential amplifier with bipolar input, } \\
\text { and CMRR }>100 \mathrm{~dB} \text {. }\end{array}$ & No \\
\hline $\begin{array}{l}\text { Resende et al., } \\
2012^{23}\end{array}$ & $\begin{array}{l}\text { Vaginal: } \\
\text { Chattanooga } \\
\text { Group }\end{array}$ & $\begin{array}{l}\text { Two contractions sustained for } \\
5 \text { s with } 30 \text {-s rest. The best of the } \\
\text { contractions was considered as } \\
\text { the MVC. }\end{array}$ & $\begin{array}{l}\text { Band-pass filter with cutoff frequencies at } 20-500 \mathrm{~Hz} \text {, an } \\
\text { amplifier gain of } 1,000 \text {, and a CMRR }>120 \mathrm{~dB} \text { and a } 12-\mathrm{bit} \\
\text { analog-to-digital signal converting plate with a } 2.0 \mathrm{kHz} \\
\text { anti-aliasing filter sampling frequency for each channel } \\
\text { was used. }\end{array}$ & No \\
\hline $\begin{array}{l}\text { Resende et al., } \\
2011^{24}\end{array}$ & $\begin{array}{l}\text { Vaginal: } \\
\text { Chattanooga } \\
\text { Group }\end{array}$ & $\begin{array}{l}\text { Three } 30 \text {-s MVCs. The best of the } \\
3 \text { contractions was used for the } \\
\text { analysis. }\end{array}$ & $\begin{array}{l}\text { Band-pass filter with cutoff frequencies at } 20-500 \mathrm{~Hz} \text {, an } \\
\text { amplifier gain of } 1,000 \text { and a CMRR }>120 \mathrm{~dB} \text { and an } \mathrm{A} / \mathrm{D} \\
12 \text {-bit analog-to-digital signal converting plate with a } \\
2.0 \mathrm{kHz} \text { anti-aliasing filter for each channel and an input } \\
\text { range of } 5 \mathrm{mV} \text { was used. }\end{array}$ & No \\
\hline $\begin{array}{l}\text { Sapsford et al., } \\
2008^{25}\end{array}$ & $\begin{array}{l}\text { Vaginal: } \\
\text { Periform }\end{array}$ & $\begin{array}{l}\text { PFM activity was conducted for } 10 \text { s } \\
\text { in } 3 \text { different sitting postures: slump } \\
\text { supported, upright unsupported, and } \\
\text { very tall unsupported. }\end{array}$ & $\begin{array}{l}\text { EMG data were bandpass-filtered between } 20 \text { and } 1000 \\
\mathrm{~Hz} \text { and sampled at } 2 \mathrm{kHz} \text { using an AMLAB-based data } \\
\text { acquisition system. }\end{array}$ & No \\
\hline
\end{tabular}


Table 3. Continuation

\begin{tabular}{|c|c|c|c|c|}
\hline Authors, year & Probe used & Data collection protocol & Frequencies and approaches to filter the signal & Normalization? \\
\hline $\begin{array}{l}\text { Smith et al., } \\
2007^{26}\end{array}$ & $\begin{array}{l}\text { Vaginal: } \\
\text { Periform }\end{array}$ & $\begin{array}{l}\text { EMG activity was recorded prior and } \\
\text { subsequent to a postural perturbation } \\
\text { in which a 1-kg weight was dropped } \\
30 \mathrm{~cm} \text { into a bucket held. Subjects } \\
\text { were instructed to remain relaxed } \\
\text { before loading and to catch the load } \\
\text { when it contacted the bucket. In the } \\
\text { first ten repetitions the subject held } \\
\text { the switch and controlled the timing } \\
\text { of the drop of the weight (expected } \\
\text { condition). In the subsequent ten } \\
\text { trials, subjects wore a blindfold and } \\
\text { earplugs and the weight release } \\
\text { was controlled by the researcher } \\
\text { (unexpected condition). }\end{array}$ & $\begin{array}{l}\text { EMG data were amplified 2,000 times, band-pass filtered } \\
\text { between } 30 \text { and } 1,000 \mathrm{~Hz} \text {, and sampled at } 2,000 \mathrm{~Hz} \text {. }\end{array}$ & Yes \\
\hline $\begin{array}{l}\text { Smith et al., } \\
2008^{27}\end{array}$ & $\begin{array}{l}\text { Vaginal: } \\
\text { Periform }\end{array}$ & $\begin{array}{l}\text { Subjects stood on a force plate during } \\
\text { six static balance conditions: eyes } \\
\text { open, eyes closed, standing on foam } \\
\text { with eyes open, standing on foam } \\
\text { with eyes closed, tandem stance, and } \\
\text { standing on a short base. }\end{array}$ & $\begin{array}{l}\text { EMG data were amplified 2,000 times, band-pass filtered } \\
\text { between } 30 \text { and } 1,000 \mathrm{~Hz} \text { and sampled at } 2,000 \mathrm{~Hz} \text {. }\end{array}$ & Yes \\
\hline $\begin{array}{l}\text { Soljanik et al., } \\
2012^{28}\end{array}$ & $\begin{array}{l}\text { Vaginal: Vso } \\
2000, \text { Haynl- } \\
\text { Elektronik } \\
\text { Corp. }\end{array}$ & $\begin{array}{l}\text { Six body positions: MVC sustained for } \\
5 \mathrm{~s} \text { and rest for } 10 \mathrm{~s} \text {, with } 10 \text {-min rest } \\
\text { between positions. }\end{array}$ & $\begin{array}{l}\text { The sEMG signal-processing unit consists of one portable } \\
\text { analog-to-digital channel of an EMG unit operating at } \\
\text { voltage between } 0 \text { and } 100 \mathrm{~V} \text {, band-pass filtered at } 50 \mathrm{~Hz} \text {. }\end{array}$ & No \\
\hline $\begin{array}{l}\text { Stüpp et al., } \\
2011^{29}\end{array}$ & $\begin{array}{l}\text { Vaginal: } \\
\text { Chattanooga } \\
\text { Group }\end{array}$ & $\begin{array}{l}\text { Three } 30 \text {-s MVCs. The best of the three } \\
\text { contractions was used for the analysis. }\end{array}$ & $\begin{array}{l}\text { Band-pass filter with cutoff frequencies at } 20-500 \mathrm{~Hz} \text {, an } \\
\text { amplifier gain of } 1,000 \text { and a CMRR }>120 \mathrm{~dB} \text {. An A/D 12-bit } \\
\text { analog-to-digital signal converting plate with a } 2.0 \mathrm{kHz} \\
\text { anti-aliasing filter sampling frequency for each channel was } \\
\text { used. The plate had an input range of } 5 \mathrm{mV} \text {. }\end{array}$ & No \\
\hline $\begin{array}{l}\text { Thompson et } \\
\text { al., } 2006^{30}\end{array}$ & $\begin{array}{l}\text { Vaginal: } \\
\text { Periform }\end{array}$ & $\begin{array}{l}\text { One contraction for } 3 \mathrm{~s} \text { and a maximal } \\
\text { straining Valsalva maneuver. The } \\
\text { EMG activity was recorded for } 3 \mathrm{~s} \text { and } \\
\text { repeated three times with 1-min rest. }\end{array}$ & $\begin{array}{l}\text { The gain setting was } 2,000 \text {, and the signal was sampled } \\
\text { at 1,000 Hz. The EMG raw data was reduced, rectified, } \\
\text { band-pass filtered at } 4-400 \mathrm{~Hz} \text { using a fourth-order zero-lag } \\
\text { Butterworth filter (National Instruments). }\end{array}$ & Yes \\
\hline $\begin{array}{l}\text { Thompson et } \\
\text { al., } 2006^{31}\end{array}$ & $\begin{array}{l}\text { Vaginal: } \\
\text { Periform }\end{array}$ & $\begin{array}{l}\text { One contraction for } 3 \mathrm{~s} \text { and a maximal } \\
\text { straining Valsalva maneuver. The } \\
\text { EMG activity was recorded for } 3 \mathrm{~s} \text { and } \\
\text { repeated three times with 1-min rest. }\end{array}$ & $\begin{array}{l}\text { The amplifier gain was } 2,000 \text {, and the signal was sampled } \\
\text { at 1,000 Hz. The EMG raw data was reduced, rectified, } \\
\text { band-pass filtered at } 4-400 \mathrm{~Hz} \text { using a fourth-order zero-lag } \\
\text { Butterworth filter (National Instruments). }\end{array}$ & Yes \\
\hline Zhang, $2006^{32}$ & $\begin{array}{l}\text { Vaginal: } \\
\text { FemiScan }\end{array}$ & $\begin{array}{l}\text { Four } 5 \text {-s contractions preceded by } 10-s \\
\text { relaxation. }\end{array}$ & No description. & No \\
\hline
\end{tabular}

EMG: electromyography; MVC: maximal voluntary contraction; PFM: pelvic floor muscles; sEMG: surface electromyography

\section{DISCUSSION}

This systematic review aimed to determine how EMG data are analyzed in the functional assessment of PFM. Only seven studies normalized the data, according to the recommendations proposed in the Guide for Use and Interpretation of Kinesiologic Electromyographic Data ${ }^{33}$.

The characteristics of the amplitude and frequency of the electromyography signal are sensitive to intrinsic (muscle fiber type, depth, diameter, and amount of tissue between the muscle and electrode) and extrinsic factors (location, orientation, and shape of the area of the electrodes). Thus, the signal amplitude cannot be analyzed directly $y^{3,5,8}$. To analyze and compare electromyography signals from different individuals, muscles, and acquisition modes, it is necessary to "normalize" them, which is a form of transforming the absolute values of the amplitude into relative values related to an amplitude value characterized at $100 \%{ }^{8}$.

Normalization methods impede any interference on the intensity of the contraction, as they remove the effect of other factors that influence on signal capture. Thus, it is only after the standardization process that we can compare different muscles and individuals considering the amount of energy produced during a given contraction ${ }^{5}$. 
We have several ways to normalize the electromyographic signal. Usually, it is performed by dividing the obtained values by a reference point. The most referenced point in the literature is the normalization by the maximum voluntary contraction (MVC); in this point, a reference is attributed to the highest value found among certain contractions from that muscle. In general, patients are oriented to perform three MVCs and the highest value is recorded. The other contractions of the collected protocol will be percentages of the $\mathrm{MVC}^{9}$. Some authors use the mean between two or three MVC as reference value $^{8}$. Another possibility of normalization is to use the maximum peak of the electromyographic signal. Similarly, the value of $100 \%$ is attributed to the maximum peak, and all the electromyographic signal is normalized using this value ${ }^{8}$.

In this systematic review, only seven studies performed the normalization of the electromyographic signal using the MVC $18-20,26,27,30,31$.

As aforementioned, the most common method for the normalization of the amplitude of the EMG signal is to use the MVC. This method quantifies more precisely the relative effort of muscular groups, allowing the comparison between patients with and without neuromuscular dysfunction. It may also be defined as the Muscular Utilization Ratio (\%), characterized by the ratio between the mechanic demand imposed during the motor activity and the maximum capacity of the muscular group to perform the activity. This ratio is multiplied by one hundred to obtain a percentage (\%) based on the MVC to develop a specific motor task ${ }^{33}$.

According to Soderberg and Knutson ${ }^{34}$, the decision to normalize or not is based on the type of description and whether one of the research objectives is to compare data. If comparisons are made between subjects, days, muscle, or studies, the normalization is required ${ }^{35}$. Meanwhile, if the subjects act independently and the collection is held on the same day, assessing the same muscle without electrode removal, the normalization is not considered necessary. However, we recommend normalization of data, because this step is required in case the results are compared with similar data from other studies in the future.

Besides depending on physiological properties, sEMG is also influenced by non-physiological properties, such as probe configuration (size, shape, how it is applied, and type of filter used for signal detection) ${ }^{8}$. Some studies have assessed the reliability of the comparison between different probes; however, few studies have evaluated this aspect in Brazil.

Ten different probes were used in the studies included in this review, except for those that did not mention the type of vaginal probe used. Data collection protocols also varied, and patients were evaluated in different positions. These are limiting factors for a systematic review of literature that seeks to evaluate the contribution of sEMG in the functional assessment of PFM in a given population. The heterogeneity of the studies hampered their comparison and systematization of data. However, positively, our study opens space for reflection and discussions on the subject to move toward a standardization of the technique used in the PFM functional assessment.

Another important factor worth mentioning is the sample heterogeneity between studies. Functional assessment of PFM of nulliparous, primiparous, and multiparous women; patients with PFM disorders, such as urinary incontinence and pelvic organ prolapse; and women in menopause and postmenopause contribute to the differences in results due to the effects of delivery, mode of delivery, and hormone changes related to aging, for example, on the PFM function. Variations in sample size and study design are also relevant factors that limit the systematization of data due to the distinct methodologies between studies.

The strength of this review is the originality and the analysis of the risk of bias with a specific tool for cohort studies ${ }^{10}$.

As weaknesses of the study we can mention the low methodological quality of the included studies. A considerable amount of the NOS scoring was lost when we analyzed the "comparability" item due to the lack of a control group for comparisons. "Outcome" was another item with a reduced score due to the lack of information on blinding and/or a follow-up long enough so that results may occur. Unfortunately, this was not found for most of the selected results.

The research question within this systematic review is very important. EMG studies are central to evaluate studies on pelvic floor training efficacy, and, as such, comparison across studies with heterogeneity in the methods used to capture sEMG activity is important.

Thus, standardization of guidelines for sEMG data collection, management, analysis, and interpretation of results in the PFM functional assessment is essential. We hope that this review alerts physiotherapists about PFM disorders regarding these issues. 


\section{REFERENCES}

1. Matheus-Vasconcelos ECL, Ribeiro AM. Força e função muscular do assoalho pélvico: como avaliar? Fisioter Bras. 2013;14(6):465-9.

2. Bø K, Sherburn M. Evaluation of female pelvic-floor muscle function and strength. Phys Ther. 2005;85(3):269-82. doi: 10.1093/ptj/85.3.269

3. Botelho S, Pereira LC, Marques J, Lanza AH, Amorim CF, Palma $P$, et al. Is there correlation between electromyography and digital palpation as means of measuring pelvic floor muscle contractility in nulliparous, pregnant, and postpartum women? Neurourol Urodyn. 2013;32(5):420-3. doi: 10.1002/nau.22321

4. Marques J, Botelho S, Pereira LC, Lanza AH, Amorim CF, Palma P, et al. Pelvic floor muscle training program increases muscular contractility during first pregnancy and postpartum: electromyographic study. Neurourol Urodyn. 2012;32(7):9981003. doi: 10.1002/nau.22346

5. Ocarino JM, Silva PLP, Vaz DV, Aquino CF, Brício RS, Fonseca ST. Eletromiografia: interpretação e aplicações nas ciências da reabilitação. Fisioter Bras. 2005;6(4):305-10.

6. Keshwani N, McLean L. State of the art review: intravaginal probes for recording electromyography from the pelvic floor muscles. Neurourol Urodyn. 2015;34(2):104-12. doi: 10.1002/ nau.22529

7. Turker KS. Electromyography: some methodological problems and issues. Phys Ther. 1993;73(10):698-710.

8. de Luca CJ. The use of surface electromyography in biomechanics. J Appl Biomech. 1997;13(2):135-63. doi: 10.1123/ jab.13.2.135

9. Burden A, Bartlett R. Normalisation of EMG amplitude: an evaluation and comparison of old and new methods. Med Eng Phys. 1999;21(4):247-57. doi: 10.1016/S1350-4533(99)00054-5

10. Stang A. Critical evaluation of the Newcastle-Ottawa scale for the assessment of the quality of nonrandomized studies in meta-analyses. Eur J Epidemiol. 2010;25(9):603-5. doi: 10.1007/s10654-010-9491-z

11. Auchincloss C, McLean L. The reliability of surface EMG recorded from the pelvic floor muscles. J Neurosci Methods. 2009;182(1):85-96. doi: 10.1016/j.jneumeth.2009.05.027

12. Chen HL, Lin YC, Chien WJ, Huang WC, Lin HY, Chen PL. The effect of ankle position on pelvic floor muscle contraction activity in women. J Urol. 2009;181(3):1217-23. doi: 10.1016/j. juro.2008.10.151

13. Devreese A, Staes F, Janssens L, Penninckx F, Vereecken R, de Weerdt W. Incontinent women have altered pelvic floor muscle contraction patterns. J Urol. 2007;178(2):558-62. doi: 10.1016/j.juro.2007.03.097

14. Frederice CP, Amaral E, Ferreira NO. Urinary symptoms and pelvic floor muscle function during the third trimester of pregnancy in nulliparous women. J Obstet Gynaecol Res. 2013;39(1):188-94. doi: 10.1111/j.1447-0756.2012.01962.x

15. Grape HH, Dedering A, Jonasson AF. Retest reliability of surface electromyography on the pelvic floor muscles. Neurourol Urodyn. 2009;28(5):395-9. doi: 10.1002/nau.20648

16. Halski T, Słupska L, Dymarek R, Bartnicki J, Halska U, Król $A$, et al. Evaluation of bioelectrical activity of pelvic floor muscles and synergistic muscles depending on orientation of pelvis in menopausal women with symptoms of stress urinary incontinence: a preliminary observational study. Biomed Res Int. 2014;2014:[8 p.]. doi: 10.1155/2014/274938

17. Halski T, Ptaszkowski K, Słupska L, Dymarek R. The evaluation of bioelectrical activity of pelvic floor muscles depending on probe location: a pilot study. Biomed Res Int. 2013;2013:[7 p.]. doi: 10.1155/2013/238312

18. Junginger B, Baessler K, Sapsford R, Hodges PW. Effect of abdominal and pelvic floor tasks on muscle activity, abdominal pressure and bladder neck. Int Urogynecol J. 2010;21(1):69-77. doi: 10.1007/s00192-009-0981-z

19. Lauper M, Kuhn A, Gerber R, Luginbühl H, Radlinger L. Pelvic floor stimulation: what are the good vibrations? Neurourol Urodyn. 2009;28(5):405-10. doi: 10.1002/nau.20669

20. Luginbuehl H, Lehmann C, Gerber R, Kuhn A, Hilfiker R, Baeyens JP, et al. Continuous versus intermittent stochastic resonancewhole body vibration and its effect on pelvic floor muscle activity. Neurourol Urodyn. 2012;31(5):683-7. doi: 10.1002/nau.21251

21. Pereira LC, Botelho S, Marques J, Amorim CF, Lanza AH, Palma $P$, et al. Are transversus abdominis/oblique internal and pelvic floor muscles coactivated during pregnancy and postpartum? Neurourol Urodyn. 2013;32(5):416-9. doi: 10.1002/nau.22315

22. Petricelli CD, Resende AP, Elito Júnior J, Araujo Júnior E, Alexandre SM, Zanetti MR, et al. Distensibility and strength of the pelvic floor muscles of women in the third trimester of pregnancy. Biomed Res Int. 2014;2014:[6 p.]. doi: 10.1155/2014/437867

23. Resende AP, Petricelli CD, Bernardes BT, Alexandre SM, Nakamura MU, Zanetti MR. Electromyographic evaluation of pelvic floor muscles in pregnant and nonpregnant women. Int Urogynecol J. 2012;23(8):1041-5. doi: 10.1007/ s00192-012-1702-6

24. Resende AP, Zanetti MR, Petricelli CD, Castro RA, Alexandre SM, Nakamura MU. Effects of the Paula method in electromyographic activation of the pelvic floor: a comparative study. Int Urogynecol J. 2011;22(6):677-80. doi: 10.1007/ s00192-010-1331-X

25. Sapsford RR, Richardson CA, Maher CF, Hodges PW. Pelvic floor muscle activity in different sitting postures in continent and incontinent women. Arch Phys Med Rehabil. 2008;89(9):1741-7. doi: 10.1016/j.apmr.2008.01.029

26. Smith MD, Coppieters MW, Hodges PW. Is balance different in women with and without stress urinary incontinence? Neurourol Urodyn. 2008;27(1):71-8. doi: 10.1002/nau.20476

27. Smith MD, Coppieters MW, Hodges PW. Postural response of the pelvic floor and abdominal muscles in women with and without incontinence. Neurourol Urodyn. 2007;26(3):377-85. doi: 10.1002/nau.20336

28. Soljanik I, Janssen U, May F, Fritsch H, Stief CG, Weissenbacher $\mathrm{ER}$, et al. Functional interactions between the fossa ischioanalis, levatorani and gluteus maximus muscles of the female pelvic floor: a prospective study in nulliparous women. Arch Gynecol Obstet. 2012;286(4):931-8. doi: 10.1007/s00404-012-2377-4

29. Stüpp L, Resende AP, Petricelli CD, Nakamura MU, Alexandre SM, Zanetti MR. Pelvic floor muscle and transversus abdominis activation in abdominal hypopressive technique through 
surface electromyography. Neurourol Urodyn. 2011;30(8):151821. doi: 10.1002/nau.21151

30. Thompson JA, O'Sullivan PB, Briffa NK, Neumann P. Altered muscle activation patterns in symptomatic women during pelvic floor muscle contraction and Valsalva manouevre. Neurourol Urodyn. 2006;25(3):268-76. doi: 10.1002/nau.20183

31. Thompson JA, O'Sullivan PB, Briffa NK, Neumann P. Differences in muscle activation patterns during pelvic floor muscle contraction and Valsalva maneuver. Neurourol Urodyn. 2006;25(2):148-55. doi: 10.1002/nau.20203

32. Zhang Q, Wang L, Zheng W. Surface electromyography of pelvic floor muscles in stress urinary incontinence.
Int J Gynaecol Obstet. 2006;95(2):177-8. doi: 10.1016/j. ijgo.2006.07.006

33. Silva Junior RA. Normalização EMG: considerações da literatura para avaliação da função muscular. Conscientiae Saúde, 2013;12(3):470-9.

34. Soderberg GL, Knutson LM. A guide for use and interpretation of kinesiologic electromyographic data. Phys Ther. 2000;80(5):485-98.

35. Winter DA. Electromyogram recording, processing, and normalization: procedures and considerations. Journal of Human Muscle Performance. 1991;1(2):5-15. 